\title{
DAMPAK KOMUNIKASI TERAPEUTIK TERHADAP CITRA PELAYANAN KESEHATAN \\ (STUDI KASUS DI RUMAH SAKIT UMUM DAERAH ARIFIN ACHMAD PEKANBARU)
}

\section{THERAPEUTIC COMMUNICATIONS IMPACT ON THE IMAGE OF HEALTH CARE (STUDY AT REGIONAL PUBLIC HOSPITAL OF ARIFIN ACHMAD PEKANBARU)}

\author{
Muhd A.R. Imam Riauan, Tessa Shasrini \\ (imamriauan@comm.uir.ac.id, tshasrini@gmail.com) \\ (Fakultas Ilmu Komunikasi, Universitas Islam Riau)
}

\begin{abstract}
Abstrak
Dalam tulisan ini, kami menunjukkan bahwa komunikasi terapeutik memiliki pengaruh atas citra pelayanan kesehatan di Rumah Sakit Umum Daerah Arifin Achmad Pekanbaru. Keyakinan dan kesan dari Pasien berdampak ke pembentukan citra pelayanan kesehatan di rumah sakit. Keterampilan berkomunikasi dalam memberikan pelayanan medis yang dilakukan dalam proses pengobatan dan penyembuhan pasien memiliki efek pada peningkatan citra pelayanan kesehatan di rumah sakit. Dengan menyediakan pelayanan komunikasi yang baik antara dokter atau perawat kepada pasien, pelayanan kesehatan dapat meningkatkan citra rumah sakit. Komunikasi terapeutik yang dilakukan untuk membangun citra positif di rumah sakit pemerintah harus dilakukan ketika seorang dokter atau perawat berkomunikasi kepada pasien untuk berinteraksi, mendengarkan, serta memahami kondisi pasien. Hasil penelitian ini diperoleh dari penelitian kuantitatif dengan menggunakan metode regresi linear statistik. Kata Kunci: Komunikasi Terapeutik, Pencitraan, Pelayanan Kesehatan
\end{abstract}

\begin{abstract}
In this paper, we show that the therapeutic communications have to influence the image of health care at Regional Public Hospital of Arifin Achmad Pekanbaru. Beliefs and impressions of the patient have impact to cunstruct the image of health care at the hospital. Communication skills in providing medical services performed in the process of treatment and cure of patients have an effect on increasing the image of the hospital health care. By providing good services communication between doctors or nurses to the patients, health care will improve the image of the hospital. Therapeutic communication are being made to construct a positive image in government hospitals should be done when a doctor or nurse to communicate to the patient to interaction, listening, and to show reception. This paper's result obtain from the quantitative research by using the reggression linear method of statistic.
\end{abstract}

Keywords: Therapeutic Communication, Image, Health Care

\section{Pendahuluan}

Rumah sakit adalah institusi dengan karateristik tersendiri yang pelayanan kesehatan bagi masyarakat dipengaruhi oleh perkembangan ilmu 
pengetahuan kesehatan, kemajuan, teknologi, dan kehidupan social ekonomi masyarakat yang harus tetap mampu meningkatkan pelayanan yang lebih bermutu dan terjangkau oleh masyarakat agar terwujud derajat kesehatan yang setinggi-tingginya (Undang- Undang RI No.44 Tahun 2009).

\section{Menurut}

Departemen

Kesehatan, rumah sakit sebagai salah satu fasilitas pelayanan kesehatan memiliki peran yang sangat strategis dalam menciptakan sumber daya manusia yang berkualitas sebagai upaya mempercepat peningkatan derajat kesehatan secara menyeluruh, merata, terjangkau dan dapat diterima oleh seluruh masyarakat. Peran strategis ini di dapat karena rumah sakit merupakan fasilitas pelayanan kesehatan yang padat, model, padat karya dan padat teknologi. Selain itu juga menerapkan nilai social dan etika serta harus mempertimbangkan segi ekonomis agar rumah sakit dapat berkembang terus. Fungsi utama rumah sakit adalah sebagai wadah pelayanan rawat jalan, gawat darurat, pelayanan medik, dan non medik. Maka pengelolaan sumber daya manusia sangat diperlukan dan bagian terpenting dalam manajemen rumah sakit terhadap peningkatan kualitas pelayanan yang diberikan.

Kualitas pelayanan merupakan suatu kondisi dinamis yang berhubungan dengan produk, jasa, manusia, proses dan lingkungan yang memenuhi atau melebihi harapan, ciri pelayanan yang berkualitas adalah yang simpatik, displin, bertanggung jawab dan penuh perhatian sehingga memberikan kepuasan atas pelayanan yang diberikan. Kualitas pelayanan yang diberikan lima dimensi yaitu : (1) keandalan (reliability), (2) bukti langsung (tangibles) (3) daya tanggap (responsiveness), (4) jaminan (assurance), (5) empati (empathy). Seiring dengan semakin kritisnya masyarakat akan tuntutan terhadap pelayanan kesehatan yang berkualitas, maka fungsi pelayanan kesehatan rumah sakit perlu ditingkatkan.

Citra adalah kesan, perasaan, gambaran dari publik terhadap perusahaan, kesan yang sengaja diciptakan dari suatu objek, orang, atau organisasi. Citra itu sengaja perlu diciptakan agar bernilai positif. Citra itu sendiri merupakan salah satu aset terpenting dari suatu perusahaan atau organisasi (Priyatna dan Ardianto, 2009: 5).

Citra terbentuk berdasarkan informasi yang diterima oleh khalayak baik secara langsung maupun melalui media, termasuk media sosial dan media massa yang bekerja menyampaikan pesan yang aktual dan faktual (Arifin, 2011: 177). Informasi yang diterima oleh khalayak tersebut bersumber dari aktivitas komunikasi yang menyebabkan terjadinya proses pertukaran informasi.

Salah satu faktor pendukung yang dapat meningkatkan citra pelayanan kesehatan adalah komunikasi terapeutik terapeutik yang dilakukan oleh perawat kepada pasien atau keluarga pasien. Komunikasi terapeutik merupakan alat untuk membina hubungan antara perawat dan pasien karena komunikasi terapeutik mencakup penyampaian informasi, pertukaran pikiran, perawat dan pasien. 
Komunikasi dalam profesi keperawatan sangatlah penting sebab tanpa komunikasi pelayanan kesehatan sulit untuk mengaplikasikan. Dalam proses asuhan keperawatan, komunikasi ditujukan untuk mengubah perilaku pasien guna mencapai tingkat kesehatan yang optimal. Komunikasi terapeutik mempunyai tujuan dan fungsi sebagai terapi bagai pasien. Karena itu pelaksanaan komunikasi terapeutik harus direncanakan dan terstruktur dengan baik. Struktur dalam proses komunikasi terapeutik terdiri dari empat tahap yaitu, tahap prainteraksi, tahap orientasi, tahap kerja, dan tahap terminasi (Suryani, 2013)

Gronroos dalam Priyatna dan
Ardianto
mengidentifikasikan salah satu peran citra bagi suatu organisasi adalah fungsi dari pengalaman dan juga harapan konsumen. Ketika konsumen membangun harapan kualitas dan realitas pengalaman dalam bentuk kualitas pelayanan teknis dan fungsional, kualitas pelayanan yang dirasakan memenuhi citra atau melebihi citra, citra akan mendapat penguatan dan bahkan meningkat.

Kotler 1995 dalam Priyatna dan Ardianto, 2009: 7) secara luas mendefinisikan citra sebagai jumlah dari keyakinan-keyakinan, gambaran-gambaran, kesan-kesan yang dipunyai seseorang pada suatu objek. Objek yang dimaksud bisa berupa orang, organisasi, kelompok orang atau yang lain yang diketahui.

Berdasarkan hal inilah rumah sakit harus mampu memberikan pelayanan sampai paripurna yaitu pelayanan menyeluruh mulai saat pertama pasien datang ke rumah sakit sampai setelah selesai berobat, yang diberikan oleh dokter dan perawat agar pasien merasa nyaman dan memperoleh kepuasan. Komunikasi yang disampaikan oleh dokter dan perawat sangat berpengaruh bagi pasien terlebih oleh seorang perawat yang menurut kenyataan hal pertama yang dijumpai pasien di rumah sakit adalah seorang perawat baik untuk melakukan tindakan mengukur tekanan darah, memberikan suntikan dan memasang infus, maka komunikasi yang terjadi pada perawat tersebut adalah disebut sebagai komunikasi terapeutik.

Tingkat kepuasan masyarakat mempunyai pengukuran keberhasilan penyelenggaraan pelayanan yang di tentukan oleh tingkat kepuasan penerima pelayanan. Salah satu hubungan antar manusia yang memprioritaskan hubungan yang baik antara komunikator dan komunikan adalah hubungan dokter dan pasien. Pada zaman modern, hubungan ini disebut transaksi terapeutik atau kontrak terapeutik antara tenaga kesehatan dengan pasien. Hubungan kerjasama yang baik antara perawat dengan pasien tidak terlepas dari peran komunikasi itu sendiri. Komunikasi yang diberikan bukanlah komunikasi sosial biasa, melainkan komunikasi terapeutik yang merupakan komunikasi antara perawat dengan pasien yang dilakukan secara sadar, selain itu bertujuan untuk kesembuhan pasien.

Komunikasi terapeutik adalah komunikasi yang direncanakan secara sadar, bertujuan dan kegiatan nya dipusatkan untuk kesembuhan pasien. Keberadaan komunikasi terapeutik memiliki peranan yang 
penting dalam membantu klien dalam memecahkan masalah yang dihadapinya.

Salah satu bentuk produk pelayanan pemerintah kepada masyarakat adalah pelayanan dibidang kesehatan. Kesehatan adalah merupakan salah satu dari hak asasi manusia, seperti termaktub dalam UUD 1945. Dalam UUD 1945 juga dinyatakan bahwa setiap orang berhak hidup sejahtera lahir dan batin, bertempat tinggal dan mendapatkan lingkungan hidup yang baik dan sehat serta berhak memperoleh pelayanan kesehatan. Kesehatan sebagai hak asasi manusia, mengandung suatu kewajiban untuk menyehatkan yang sakit dan berupaya mempertahankan yang sehat untuk tetap sehat. Kesehatan adalah keadaan sejahtera dari badan, jiwa dan sosial yang memungkinkan setiap orang hidup produktif secara sosial dan ekonomis. Hal ini melandasi pemikiran bahwa sehat adalah investasi.

Dalam memberikan pelayanan kesehatan masyarakat, RSUD Arifin Achmad menjadi rumah sakit terbesar sebagai rumah sakit pemerintah yang melakukan pelayanan kesehatan dari pemerintah Provinsi Riau kepada masyarakat. RSUD Arifin dipilih sebagai objek penelitian dalam penelitian ini disebabkan perannya sebagai rumah sakit pemerintah yang menjadi pilihan masyarakat untuk mendapatkan fasilitas kesehatan dari pemerintah. Hal tersebut semakin dikuatkan dengan tingginya biaya kesehatan yang harus dikeluarkan oleh masyarakat ketika harus berobat di Rumah Sakit Swasta. RSUD
Arifin Ahmad dalam operasionalnya juga menerima anggaran yang bersumber dari APBD Riau yang berasal dari uang masyarakat Riau. Dengan demikian masyarakat memiliki ketergantungan yang besar terhadap kualitas pelayanannya.

Pada kenyataannya, citra pelayanan kesehatan yang diberikan oleh RSUD Arifin Achmad masih belum mampu menjawab kebutuhan masyarakat terhadap pelayanan kesehatan. Hal ini dapat dilihat dari pelayanan kesehatan yang dikeluhkan oleh masyarakat yang dapat kita temui dari pembicaraan masyarakat baik secara langsung ataupun yang terekspos melalui media massa.

Salah satu pemberitaan yang diekspos adalah melalui media online, tribunpekanbaru.com yang memberikan dengan judul berita "Eny Keluhkan Layanan RSUD Arifin Ahmad" (tribunpekanbaru.com, 28 Mei 2014), "Warga Keluhkan Buruknya Layanan RSUD AA ke Anggota DPRD Riau" (riauterkini.com, 27 Februari 2013), ditambah lagi dengan pemberitaan dari anggota dewan yang meminta agar memperhatikan kesejahteraan RSUD Arifin Achmad agar dapat melayani pasien dengan baik (antarariau.com, 12 Januari 2015). Pemberitaan tersebut dapat menggambarkan keluhan masyarakat tentang pelayanan kesehatan di RSUD Arifin Achmad sehingga dapat semakin memperburuk citra pelayanan kesehatan di RSUD Arifin Achmad.

Beberapa pemberitaan tersebut menunjukkan adanya permasalahan dengan pelayanan kesehatan yang diberikan oleh pihak RSUD Arifin 
Ahmad kepada pasien. Beberapa pasien tidak puas terhadap pelayanan yang diberikan sehingga memberikan komplain hingga berbicara kepada media. Media melakukan pemberitaan tentang peristiwa yang sifatnya aktual dan faktual. Dengan demikian munculnya pemberitaan tersebut berdasarkan dari kejadian nyata yang terjadi di rumah sakit umum daerah terkait pelayanan rumah sakit umum daerah (RSUD) Arifin Ahmad.

Pelayanan kesehatan sangat tergantung terhadap kelas perawatan yang dipilih oleh pasien. Pasien yang memilih kelas yang baik akan mendapatkan pelayanan yang lebih baik. Akan tetapi dalam melaksanakan tugasnya memberikan pelayanan kesehatan, komunikasi tentang kondisi pasien dan pengobatan pasien harus disampaikan dengan baik. Kelas yang rendah akan mendapatkan fasilitas yang sesuai dengan ketentuan kelas yang rendah, kelas yang tinggi juga mendapatkan fasilitas yang lebih baik. Akan tetapi tugas memberikan pelayanan kesehatan dari sisi komunikasi terapeutik merupakan hal yang tidak bisa dibeda-bedakan.

Sementara itu, komunikasi terapeutik berhubungan dengan terapi, yang merupakan usaha untuk memulihkan kesehatan seseorang yang sedang sakit. Komunikasi terapeutik adalah pengiriman pesan antara pengirim dan penerima dengan interaksi di antara keduanya yang bertujuan memulihkan kesehatan seseorang yang sedang sakit. Tujuan komunikasi terapeutik adalah menegakkan hubungan terapeutik antara petugas dengan pasien (Maulana, 2009: 100).

Komunikasi merupakan proses yang sangat khusus dan berarti dalam hubungan antarmanusia. Pada profesi keperawatan, komunikasi menjadi lebih bermakna karena merupakan metode utama dalam mengimplementasikan proses keperawatan. Pengalaman ilmu untuk menolong sesama memerlukan kemampuan khusus dan kepedulian sosial yang besar.

Untuk itu perawat memerlukan kemampuan khusus dan kepedulian social yang mencakup keterampilan intelektual, teknikal, interpersonal yang tercermin dan perilaku caring atau kasih sayang dan cinta. Mengkomunikasikan keinginan seseorang agar bisa dituruti oleh seorang lain dan menggunakan pendekatan influensial dalam hal ini komunikasi antara perawat dank lien (pasiennya). Komunikasi dalam profesi keperawatan sangatlah penting sebab tanpa komunikasi pelayanan keperawatan sulit untuk diaplikasikan.

Menurut Purwanto, komunikasi terapeutik adalah komunikasi yang direncanakan secara sadar dan bertujuan serta kegiatannya difokuskan untuk kesembuhan pasien dan merupakan komunikasi professional yang mengarah pada tujuan untuk menyembuhkan pasien (Sya'diyah, 2013: 75). Komunikasi terapeutik adalah komunikasi yang direncanakan secara sadar dan bertujuan serta kegiatannya difokuskan untuk kesembuhan pasien dan merupakan komunikasi professional yang mengarah pada tujuan untuk menyembuhkan pasien (Sya'diyah, 2013:75). 


\begin{abstract}
Northhouse dalam Suryani (2013: 12) menyatakan bahwa komunikasi terapeutik adalah kemampuan atau keterampilan perawat untuk membantu klien beradaptasi terhadap stres, mengatasi gangguan psikologis, dan belajar bagaimana berhubungan dengan orang lain. Sedangkan Stuart G.W. dalam Suryani (2013: 12) menyatakan bahwa komunikasi terapeutik merupakan hubngan interpersonal antara perawat dan klien, dalam hubungan perawat ini perawat dan klien memiliki pengalaman belajar bersama dalam rangka memperbaiki pengalaman emosional klien.
\end{abstract}

Dari definisi tersebut bisa kita simpulkan bahwa komunikasi terapeutik merupakan komunikasi yang dilakukan oleh perawat kepada pasien dalam bentuk komunikasi interpersonal untuk membantu klien mengatasi gangguan psikologis untuk mempercepat proses kesembuhan. Artinya komunikasi ini dilakukan untuk memberikan terapi kepada pasien untuk memiliki motivasi kesembuhan yang kuat. Perawat memberikan keyakinan kepada pasien agar pasien memiliki semangat untuk sembuh. Motivasi yang telah hadir tersebut menjadikan pasien terpengaruh secara persuasif untuk mengikuti proses pengobatan yang telah diberikan oleh dokter agar bisa kembali sehat.

Komunikasi terapeutik mempunyai tujuan untuk memotivasi dan mengembangkan pribadi klien kearah yang lebih kontruktif dan adaptif. Selain itu komunikasi terapeutik juga diarahkan pada pertumbuhan klien yang meliputi hal-hal berikut ini:
a. Penerimaan diri dan peningkatan terhadap penghormatan diri

Klien yang sebelunya tidak menerima diri apa adanya atau merasa rendah diri, setelah berkomunikasi terapeutik dengan perawat dan bidan akan mampu menerima dirinya. Diharapkan perawat atau bidan dapat mengubah cara pandang klien tentang dirinya dan masa depannya sehingga klien dapat menghargai dan menerima diri apa adanya.

b. Kemampuan pembinaan hubungan interpersonal yang tidak superficial dan saling bergantungan dengan orang lain.

c. Peningkatan fungsi dan kemampuan untuk memuaskan kebutuhan dan mencapai tujuan yang realities.

d. Rasa indentitas personal yang jelas dan meningkatkan integritas diri.

Identitas personal yang dimaksud adalah status, peran, dan jenis kelamin klien. Klien yang mengalami gangguan identitias personal biasanya tidak mempunyai rasa percaya diri dan juga memiliki harga diri yang rendah.

Tiap klien mempunyai pikiran, perasaan, pengalaman, latar belakang budaya, agama, status sosial, ekonomi dan kebutuhan berbedabeda.Tiap klien juga memberikan respons yang berbeda-beda dalam menghadapi masalah. Ada yang mampu mengatasinya dan ada yang tidak dapat mengatasinya. Hal ini tentu bergantung pada koping yang dimiliki dan ada tidaknya support system (sistem pendukung). Selain itu, ketika mengalami masalah, tiap 
individu mengalami hal yang berbeda pula. Ada yang mampu mengungkapkan dan ada yang tidak mampu mengungkapkan. Untuk itu diperlukan dokter dan perawat yang mempunyai kepekaan terhadap berbagai respons klien, mempunyai kemampuan analisis yang cukup tinggi, dan kemampuan menanggapi respons tersebut.

Dalam menanggapi respons yang disampaikan klien, dokter perlu memahami teknik komunikasi terapeutik. Menurut Kamus Bahasa Indonesia, teknik adalah cara yang dilakukan seseorang dalam rangka mengimplementasikan suatu metode. Perry dan Potter (dalam Maulana, 2009: 100) mengatakan bahwa terdapat beberapa teknik komunikasi terapeutik yang meliputi interaksi sosial, menyimak dengan penuh perhatian, menunjukan penerimaan, mengajukan pertanyaan yang berhubungan, menjelaskan, fokus, menetapkan observasi, memberikan informasi, mempertahankan ketenagaan, dan menyimpulkan.

Gronroos dalam Priyatna dan Ardianto (2009: 9) mengidentifikasikan salah satu peran citra bagi suatu organisasi adalah fungsi dari pengalaman dan juga harapan konsumen. Ketika konsumen membangun harapan kualitas dan realitas pengalaman dalam bentuk kualitas pelayanan teknis dan fungsional, kualitas pelayanan yang dirasakan memenuhi citra atau melebihi citra, citra akan mendapat penguatan dan bahkan meningkat.

Kotler (dalam Priyatna dan Ardianto, 2009: 7) secara luas mendefinisikan citra sebagai jumlah dari keyakinan-keyakinan, gambaran-gambaran, kesan-kesan yang dipunyai seseorang pada suatu objek. Objek yang dimaksud bisa berupa orang, organisasi, kelompok orang atau yang lain yang diketahui.

Rumah sakit merupakan suatu institusi yang fungsi utamanya memberikan pelayanan kesehatan kepada masyarakat. Tugas rumah sakit adalah melaksanakan upaya kesehatan secara berdaya guna dan berhasil guna dengan mengutamakan upaya penyembuhan dan pemulihan yang dilaksanakan secara serasi dan terpadu dengan upaya peningkatan dan pencegahan serta melaksanakan upaya rujukan. Untuk dapat menyelenggarakan upaya-upaya tersebut dan mengelola rumah sakit agar tetap dapat memenuhi kebutuhan pasien dan masyarakat yang dinamis, maka setiap komponen yang ada di rumah sakit harus terintegrasi dalam satu sistem.

Puspita (2009: 27) menyatakan bahwa Pelayanan kesehatan meliputi:

1. Pelayanan medis, merupakan pelayanan yang diberikan oleh tenaga medis yang profesional di bidangnya baik doter umum maupun dokter spesialis.

2. Pelayanan keperawatan, merupakan pelayanan yang bukan tindakan medis terhadap pasien, tetapi merupakan tindakan keperawatan yang dilakukan oleh perawat sesuai aturan keperawatan.

3. Pelayanan penunjang medik yang diberikan terhadap pasien seperti: pelayanan gizi, laboratorium, farmasi, rehabilitasi medik, dan lainlain

4. Pelayanan administrasi dan keuangan, pelayanan administrasi antara lain salah 
satunya adalah bidang ketatausahaan seperti pendaftaran, rekam medis, dan kerumahtanggaan. Sedangkan keuangan adalah seperti pembayaran biaya rawat inap dan lain-lain.

Dengan demikian konsep citra pelayanan kesehatan adalah citra yang merupakan keyakinan, gambaran, dan kesan yang diperoleh terhadap pelayanan kesehatan yang meliputi pelayanan medis pelayanan keperawatan, pelayanan penunjang medik, dan pelayanan administrasi dan keuangan.

Kerangka pemikiran merupakan model konseptual tentang bagaimana landasan teori yang telah dijabarkan berhubungan secara logis dengan berbagai faktor yang diidentifikasi sebagai masalah yang penting. Sebuah model yang baik dapat menjelaskan hubungan antar variabel penelitian, yakni variabel independen dan variabel dependen. Berikut kerangka pemikiran yang disusun dalam penelitian ini:

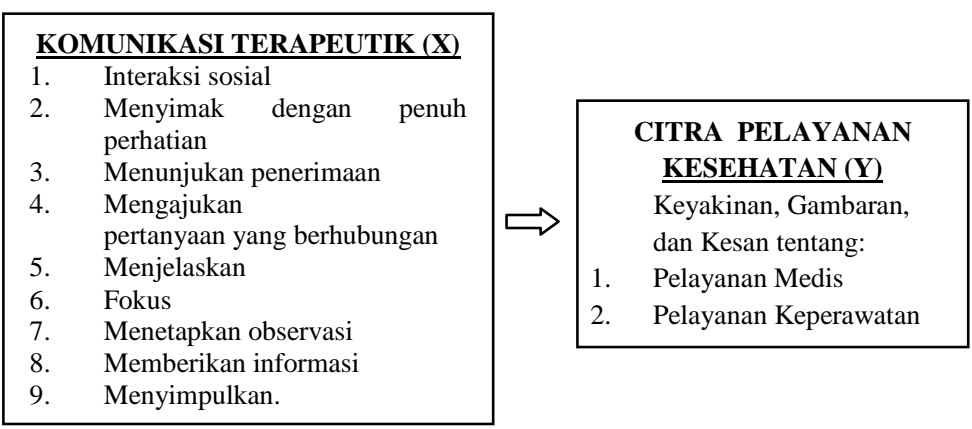

Gambar 1. Kerangka Pemikiran

Dalam penelitian ini peneliti berasumsi bahwa komunikasi terapeutik yang dijalankan oleh dokter dan pasien dalam proses penyembuhan memiliki dampat terhadap citra pelayanan kesehatan dalam proses penyembuhan pasien.
Sejalan dengan pendapat Perry dan Potter dalam (Maulana, 2009: 100) yang menyatakan bahwa teknik komunikasi yang terapeutik meliputi interaksi sosial, menyimak dengan penuh perhatian, menunjukan penerimaan, mengajukan pertanyaan yang berhubungan, menjelaskan, fokus, menetapkan observasi, memberikan informasi, mempertahankan ketenagaan, dan menyimpulkan. Dengan demikian peneliti merumuskan pendapat tersebut menjadi indikator untuk mengukur variabel komunikasi terapeutik yang kemudian disebut dengan variabel $\mathrm{X}$.

Sedangkan variabel citra pelayanan kesehatan yang kemudian disebut dengan variabel $\mathrm{Y}$ akan diukur dengan konsep citra pelayanan yang menggabungkan konsep dari Kotler dan Puspita tentang citra dan pelayanan kesehatan sehingga variabel citra pelayanan kesehatan tersebut diukur dengan indikator keyakinan, gambaran, dan kesan yang diperoleh terhadap pelayanan kesehatan yang meliputi pelayanan medis danpelayanan keperawatan.

Dengan demikian dalam kerangka penelitian ini tim peneliti mengajukan kerangka penelitian yang berasumsi bahwa terdapat kontribusi dari variabel $\mathrm{X}$ yaitu komunikasi terapeutik terhadap variabel $\mathrm{Y}$ yang disebut dengan citra pelayana kesehatan.

\section{Metodologi}

Metode dalam penelitian ini adalah penelitian kuantitatif yang analisisnya secara umum menggunakan analisis statistik. Penelitian kuantitatif adalah riset 
yang menggambarkan atau menjelaskan suatu masalah yang hasilnya dapat digeneralisasikan (Kriyantono, 2007: 57). Penelitian kuantitatif berdasarkan ada pendekatan positivisme (Kriyantono, 2007: 52). Pendekatan positivisme dilandasi pada suatu asumsi bahwa suatu gejala dapat diklarifikasikan, dan hubungan gejala bersifat klausal (sebab akibat) (Sugiyono, 2010: 23).

Metode penelitan yang dipergunakan dalam penelitian ini adalah metode survey. Metode survey adalah metode riset dengan menggunakan kuesioner sebagai instrumen pengumpulan datanya. Tujuan untuk memperoleh informasi tentang sejumlah responden yang dianggap mewakili populasi tertentu (Kriyantono, 2007: 60).Jenis penelitian ini adalah penelitian survey eksplanatif. Penelitian ini digunakan bila periset ingin mengetahui mengapa situasi atau kondisi tertentu terjadi atau apa yang mempengaruhi terjadinya sesuatu. Peneliti tidak sekedar menggambarkan terjadinya fenomena tetapi mencoba menjelaskan mengapa fenomena itu terjadi dan apa pengaruhnya (Kriyantono, 2007: 61). Penelitian eksplanatif adalah penelitian yang dilakukan untuk menemukan penjelasan tentang mengapa suatu kejadian atau gejala terjadi. Hasil akhir dari penelitian ini adalah gambaran mengenai hubungan sebab akibat. Tujuan dari penelitian eksplanatif adalah menghubungkan pola-pola yang berbeda namun memiliki keterkaitan, dan menghasilkan pola hubungan sebab akibat.
Populasi pada penelitian ini adalah seluruh pasien yang dirawat di ruang kelas 3 RSUD Arifin Achmad. Gedung kelas 3 RSUD Arifin Achmad berkapasistas 192 orang pasien. Dengan demikian jumlah populasi dalam penelitian ini adalah sebanyak 192 orang pasien/keluarga pasien.Peneliti mengambil sampel yang merupakan sebagian dari jumlah populasi untuk diteliti. Berdasarkan jumlah populasi yang diambil, maka untuk menentukan jumlah sampel yang representative penulis menggunakan teknik penarikan sampel berdasarkan Rumus Yamane (dalam Rakhmat, 2004: 82). Dengan demikian, maka jumlah populasi 192 diperoleh ukuran sampel sebesar 65,75 atau 66 sampel penelitan. Selanjutnya peneliti menggunakan teknik random sampling dalam memilih pasien yang akan dijadikan sebagai sampel penelitian.

\section{Hasil dan Pembahasan}

Penelitian menunjukkan sebuah model yang bisa digunakan untuk mengukur seberapa besar pengaruh komunikasi terapeutik terhadap citra pelayanan kesehatan di RSUD Arifin Achmad. Sebuah model yang baik dapat menjelaskan hubungan antar variabel penelitian, yakni variabel independen dan variabel dependen. Sehingga dalam penelitian ini dihasilkan dengan jelas bagaimana komunikasi terapeutik mempengaruhi citra pelayanan kesehatan.

Berdasarkan hasil analisis data mulai dari uji validitas, reliabilitas, hingga analisis regresi linier berganda, maka peneliti menemukan bahwa dalam penelitian ini teradapat 
pengaruh komunikasi terapeutik terhada citra pelayanan kesehatan. Indikator yang digunakan dalam variabel independen dan variabel dependen dinyatakan valid untuk mengukur variabel dalam penelitian ini. Dengan demikian hasil pengujian hipotesis dengan menggunakan analisis regresi linier berganda tersebut, dapat disimpulkan melalui gambar berikut:
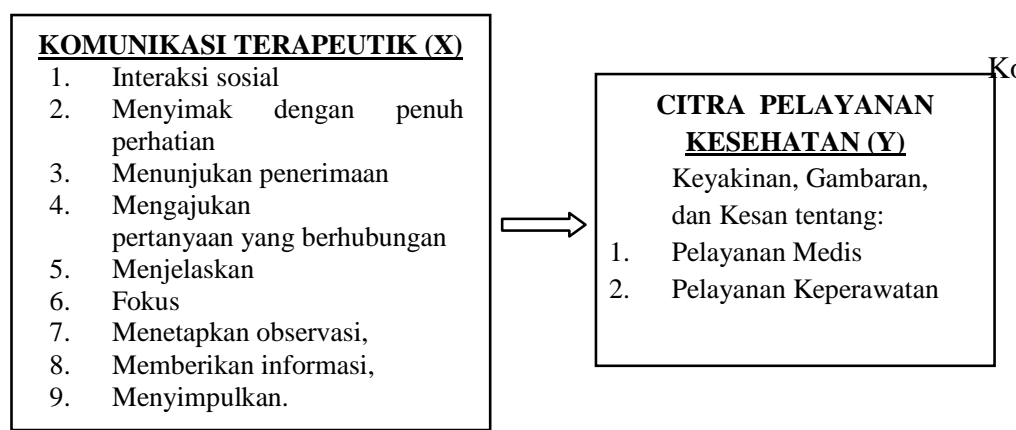

Gambar 2. Pengaruh Komunikasi Terapeutik terhadap Citra Pelayanan Kesehatan

Gambar 2. menjelaskan bahwa komunikasi terapeutik dapat mempengaruhi citra pelayanan kesehatan. Variabel komunikasi terapeutik (X) diukur dengan 9 indikator yaitu: interaksi sosial, menyimak dengan penuh perhatian, menunjukan penerimaan, mengajukan pertanyaan yang berhubungan, menjelaskan, fokus, menetapkan observasi, memberikan informasi, dan menyimpulkan.

Sedangkan variabel citra pelayanan kesehatan yang kemudian disebut dengan variabel $\mathrm{Y}$ diukur dengan konsep citra pelayanan yang menggabungkan konsep dari Kotler dan Puspita tentang citra dan pelayanan kesehatan sehingga variabel citra pelayanan kesehatan tersebut diukur dengan indikator keyakinan, gambaran, dan kesan yang diperoleh terhadap pelayanan kesehatan yang meliputi pelayanan medis danpelayanan keperawatan.

Berikut pembahasan hasil penelitian dalam penelitian ini:

1. Komunikasi Terapeutik

\begin{tabular}{|c|c|c|}
\hline Skor & Frekuensi & Pesentasi \\
\hline Tidak Setuju & 7 & 0,5 \\
\hline Kurang Setuju & 73 & 5,0 \\
\hline Setuju & 973 & 67,0 \\
\hline Sangat Setuju & 399 & 27,5 \\
\hline Total & 1452 & 100,0 \\
\hline
\end{tabular}

Komunikasi terapeutik 1: sangat tidak setuju, 2: tidak setuju,

3: kurang setuju, 4: setuju, 5: sangat setuju

Tabel 1. Frekuensi Variabel

Komunikasi Terapeutik (X)

Distribusi data komunikasi terapeutik dari 60 responden terlihat bahwa komunikasi terapeutik berjalan dengan baik pada saat pasien dirawat di RSUD Arifin ahmad. Hanya ada 0,5 persen pertanyaan dari seluruh pertanyaan yang dijawab oleh responden dalam penelitian ini yang diajwab tidak setuju. Sedangkan pertanyaan yang dijawab dengan jawaban kurang setuju hanya sebesar 5 persen. Artinya 94,5 persen pertanyaan yang dijawab oleh 66 orang respoden setuu bahwa pelaksanaan komunikasi terpeutik sudah dilakukan dengan baik sesuai dengan konsep komunikasi terapeutik yang digunakan oleh peneliti sebagai alat ukur variabel komunikasi terapeutik.

Distribusi frekuensi data komunikasi terapeutik dalam penelitian ini dapat dilihat dari grafik histogram pada gambar 3. Distribusi data komunikasi yang ditampilkan pada grafik histogram tersebut menunjukkan bahwa jawaban yang berkaitan dengan komunikasi terapeutik didominiasi dengan jawaban setuju dan sangat setuju. 
Sedangkan respon negatif yaitu jawab kurang setuju atau tidak setuju serta jawaban sangat tidak setuju tampak tidak sangat kecil data yang tampak dari grafik tersebut. Dengan demikian peneliti menyimpulkan bahwa komunikasi terapeutik sudah dilaksanakan dengan baik berdasarkan respon dari sampel penelitian ini.

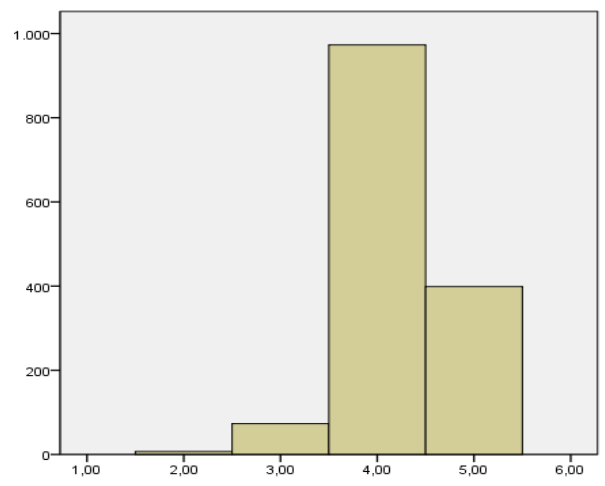

Gambar 3. Frekuensi Variabel Komunikasi Terapeutik (X)

2. Citra Pelayanan Kesehatan

\begin{tabular}{|c|c|c|}
\hline Skor & Frekuensi & Presentasi \\
\hline Tidak Setuju & 2 & 0,3 \\
\hline Kurang Setuju & 65 & 10,9 \\
\hline Setuju & 414 & 69,7 \\
\hline Sangat Setuju & 113 & 19,0 \\
\hline Total & 594 & 100,0 \\
\hline
\end{tabular}

Citra Pelayanan Kesehatan 1: sangat tidak setuju, 2: tidak setuju, 3: kurang setuju, 4: setuju, 5: sangat setuju

Tabel 2. Frekuensi Variabel

Komunikasi Terapeutik(X)

Data frekuensi dari citra pelayanan kesehatan di RSUD Arifin achmad dapat dilihat dari tabel 4.11. di atas. Tabel tersebut menunjukkan tingginya tingkat frekuensi citra RSUD Arifin Achmad jika diukur dari gambaran, keyakinan, dan kesan pasien yang telah merasakan komunikasi terapeutik setelah dirawat di RSUD Arifin Achmad. Hal ini dilihat dari pertanyaan tidak setuju hanya dijawab oleh 0,3 persen dari total seluruh item pertanyaan penelitan yang berjumah 594 item pertanyaan untuk yang digunakan untuk mengukur citra pelayanan kesehatan. Yang kurang setuju bahwa citra pelayanan kesehatan di RSUD sudah baik hanya dijawab sebanyak 10,9 persen dari total item pertanyaan artinya pernyataan negatif yang muncul dari citra pelayanan kesehatan adalah sebesar 11,2 persen. Sisanya sebesar 88,7 persen pertanyaan di respon positif.

Artinya hampir seluruh responden merespon positif pernyataan dalam kuesioner yang menandakan bahwa citra pelayanan kesehatan berdasarkan keyakinan, kesan dan gambaran pasien RSUD Arifin Achmad khususnya di kelas 3 menunjukkan bahwa citra pelayabab kesehatan di RSUD Arifin Achmad sudah baik.

Hal tersebut juga dapat dilihat dalam grafik histogram sebagai berikut:

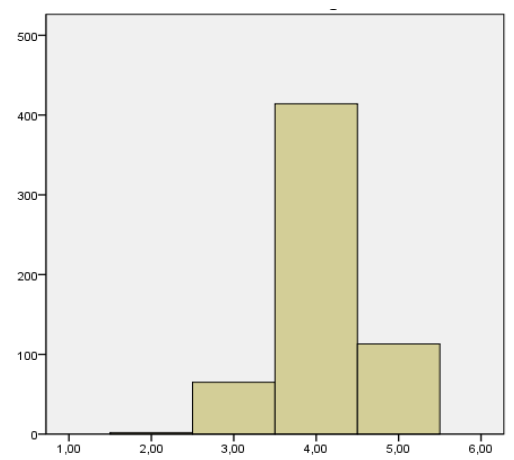

Gambar 4. Frekuensi Variabel Citra Pelayanan Kesehatan (Y)

Distribusi data citra pelayanan kesehatan yang ditampilkan tersebut menunjukkan bahwa respon yang muncul didominasi dengan jawaban setuju dan sangat setuju. Sedangkan respon negatif yaitu jawab kurang setuju atau tidak setuju serta jawaban sangat tidak setuju tampak tidak 
sangat. Dengan demikian peneliti menyimpulkan bahwa komunikasi terapeutik sudah dilaksanakan dengan baik berdasarkan respon dari sampel penelitian ini.
3. Pengaruh Komunikasi
Terapeutik terhadap Citra Pelayanan Kesehatan
Pengaruh
Komunikasi

Terapeutik (X) terhadap Citra

Pelayanan Kesehatan (Y) menghasilkan persamaan regresi $\mathrm{Y}=$ $0,747+0,548 \quad \mathrm{X}$. Koefisien determinasi menunjukkan pengaruh sebesar 0,400 yang berarti komunikasi terapeutik yang telah dilakukan oleh perawat di gedung kelas 3 RSUD Arifin Achmad memiliki peranan untuk mempengaruhi citra pelayanan sebesar $40 \%$. Sisanya sebesar $60 \%$ dijelaskan oleh variabel lain yang tidak termasuk dalam model analisis regresi linier dalam penelitian ini.

Dalam penelitian ini diketahui nilai koefisienregresi sebesar $0,633 \neq$ 0 dan nilai koefisien determinasi ( $\mathrm{R}$ Square) sebesar $0,400 \neq 0$, Sedangkan sig. probabilitas adalah 0,000 atau lebih kecil dari 0,05. Dengan demikian Ho ditolak dan $\mathrm{H}_{1}$ diterima yang berarti terdapat pengaruh antara komunikasi terapeutik terhadap citra pelayanan kesehatan.

$$
\text { Komunikasi terapeutik }
$$

memiliki pengaruh sebesar $40 \%$ terhadap citra pelayanan kesehatan. Hal ini menunjukkan bahwa komunikasi terapeutik yang dilakukan oleh dokter dan perawat, mampu memberikan pengaruh terhadap citra pelayanan kesehatan. Pengaruh tersebut disebabkan oleh jawaban responden yang merespon indikator dalam kuesioner penelitian ini dengan baik. Sehingga hal tersebut memberikan positif dan memberikan kontribusi positif pula terhadap citra positif.

\section{Penutup}

Berdasarkan hasil analisis data yang telah dilakukan dalam penelitian tentang pengaruh komunikasi terapeutik(X) terhadap Citra pelayanan kesehatan (Y), maka dapat disimpulkan sebagai berikut:

1. Komunikasi terapeutik

Pelaksanaan komunikasi terapeutik di gedung kelas 3 RSUD Arifin Achmad dinilai sudah baik. Hal tersebut berdasarkan respon jawaban penelitian yang setuju bahwa komunikasi terapeutik sudah baik sebesar $94,5 \%$ sedangkan respon negatif yaitu tidak setuju dan kurang setuju hanya sejumlah 5,5\% sedang pasien atau keluarga pasien yang sangat tidak setuju sebesar $0 \%$.

2. Citra Pelayanan Kesehatan

Pelayanan kesehatan gedung kelas 3 RSUD Arifin achmad memiliki citra positif. Hal tersebut berdasarkan dari jawaban penelitian yang menunjukkan bahwa hanya 11,2 persen pertanyaan citra pelayanan kesehtan yang direspon negatif sedangkan sisanya sebesar 88,7 persen pertanyaan di respon positif.

Terdapat pengaruh antara Komunikasi Terapeutik (X) terhadap Citra Pelayanan Kesehatan (Y) dengan persamaan regresi $\mathrm{Y}=0,747$ $+0,548 \mathrm{X}$ dengan Koefisien determinasi sebesar 0,400 yang berarti komunikasi terapeutik dapat mempengaruhi citra pelayanan sebesar $40 \%$. Sisanya sebesar $60 \%$ dijelaskan oleh variabel lain yang 
tidak termasuk dalam model analisis regresi linier dalam penelitian ini.

Dalam penelitian ini diketahui nilai koefisienregresi sebesar $0,633 \neq$ 0 dan nilai koefisien determinasi $(\mathrm{R}$ Square) sebesar $0,400 \neq 0$, Sedangkan sig. probabilitas adalah 0,000 atau lebih kecil dari 0,05. Dengan demikian Ho ditolak dan $\mathrm{H}_{1}$ diterima yang berarti terdapat pengaruh antara komunikasi terapeutik terhadap citra pelayanan kesehatan.

\section{Daftar Pustaka}

Arifin, Anwar. (2011). Komunikasi Politik, Filsafat, Paradigma, Teori, Tujuan, Strategi, dan Komunikasi Politik Indonesia. Yogyakarta: Graha Ilmu.

Kriyantono, Rachmat. (2007). Teknik Praktis Riset Komunikasi. Jakarta: Kencana Prenada Media Group.

Maulana, Heri D.J. (2009). Promosi Kesehatan. Jakarta: EGC.

Nasir dkk. (2009). Komunikasi Dalam Keperawatan: Teori dan Aplikasi. Jakarta: Salemba Medika.

Priyatna, Ardianto. (2009) Tujuh Pilar Strategi Komunikasi Bisnis. Jakarta: Widya Padjajaran.

Rakhmat, Jalaluddin. (2004). Metode Penelitian

Komunikasi. PT. Remaja

Rosda Karya: Bandung.

Sugiyono. (2010). Metode

Penelitian Administrasi.

Alfabeta: Bandung.

Suryani. (2013) Komunikasi Terapeutik: Teori dan Praktik, Jakarta: EGC.

Sya'diyah, Hidayatus. (2013). Komunikasi Keperawatan
(Communication Games

Application). Yogyakarta:

Graha Ilmu.

Puspita. (2009). http://repository.usu.ac.id/bitstr eam/123456789/30970/4/ Chapter \%20II. pdf

Antara

Riau. http://foto.antarariau.com/berit a/50626/rsud-arifin-achmaddiminta-perhatikankesejahteraan-perawat, diakses 12 Januari $2015 \quad 19.54$ WIB, Bayu Agustari Adha. http://riauterkini.com/sosial.php? arr $=56948$, diakses 27 Februari 2013 19.47 WIB.

http://pekanbaru.tribunnews.com/201 4/05/28/eny-keluhkan-layananrsud-arifin-achmad. 